\title{
ADMINISTRATIVE LAW: MATERIAL, PROCESSUAL AND FORMAL COMPONENTS
}

The purpose of the paper is to analyze and disclose the issues of theoretical and practical plan that prevent the solution of administrative law legal applying issues, which contain or are connected with the definitions of "substantive and processual law" and "norms substantive and processual law" and the development of theoretical proposals needed to solve the problems of the practical plan. Research methods. The paper uses a comprehensive approach to creating a theoretical picture of the object and the application of the methodological scheme of "double knowledge" about the object as such and the knowledge that describes and depicts it; method of comparative legal and doctrinal knowledge of administrative legislation; method of generalization and modeling of new theoretical knowledge of administrative law. Results. Issues for the further development of theory and practice of administrative law are identified and a theoretical approach for their solution is suggested. It is established that the subject of administrative law requires modeling and legal regulation of an administrative activity according to the scheme of legal certainty by the norms of substantive and formal law. Substantive administrative law consists of rules that describe materialized objects, the title of which defines the basic institutions of administrative law. Formal administrative law consists of norms that determine the process of substantive law formalization according to the procedures of administrative activity, which consist of substantive and processual norms of formal law. The main substantive rules of formal law include public conditions and formalities, as legal means that determine the interaction of subjects in administrative activity and the delimitation of the spheres of norms effect for private and public law. Conclusions. It gives reasons for the position that the practical implementation of approaches based on the theoretical position of the division into substantive and formal administrative law, means the formation of an administrative procedure as a single standard for the whole administrative activity, including judicial.

Key words: administrative law, substantive law, formal law, administrative activity, public-administrative activity, public formalities, material norms, processual norms. 
Yuriy Kunev,

Professor

at the Department

of Constitutional

and Administrative Law

of the Faculty of Law

of National Aviation

University,

Doctor of Law, Professor orcid.org/0000-0002-5952-2052 kunev@ukr.net

\section{Oksana Myronets,}

Associate Professor at the Department of Constitutional and Administrative Law of the Faculty of Law of National Aviation University,

PhD in Law,

Doctoral Student orcid.org/0000-0002-5035-2384 o.m.myronets@ukr.net

\section{Introduction}

In their decisions, courts of Ukraine of all levels and instances widely use terms: "a norm of substantive law", "a norm of substantive law of Ukraine". At the same time, courts make decisions establishing "whether the norms of substantive law have been chosen correctly" and "whether norms of substantive law have been applied correctly or are to be applied by sides", substantiating the legality of a court decision or qualifying events for compliance with a legal composition of the legal norm. In all processual codes of Ukraine, "a qualification mechanism" was in fact called "the correctness of the substantive law norms application", including it in a concept of legality of a court decision.

The legislation of Ukraine does not explicitly specify and define the content and essence of the concepts: "substantive and procedural law" and "a norm of substantive and procedural law", although the concepts are widely used in the theory of administrative law and legislation to define norms regulating an administrative activity, an administrative process.

During the research, there is an issue with the ambiguous definition of basic legal concepts relating to "substantive and procedural". At the theoretical level, its solution requires each time the explanation of the content that a researcher invests in a concept and for what purpose. A law applying person has a different situation, all the basic concepts of their essence and content have to be clarified and enshrined in the legislation in advance. Otherwise, this leads to a random interpretation of the content of legislative norms by a law applying person, which is, obviously, should be unacceptable.

The division into substantive and procedural law does not lead to the solution of the main methodological issues of scientific cognition and education. Any effective scientific theoretical approach has to have a sufficient methodological tool for the legal organization of the activity.

To make an analysis of recent research and publications we would like to represent a number of scientists' opinions that will give a general idea of the content of this issue.

According to $\mathrm{V}$. Averianov, substantive norms of administrative law establish the legal boundaries and scope of legal regulation, determine rights, duties, and liability 
of participants in regulated social relations, id est in fact their administrative-legal status. The vast majority of processual norms of administrative law contribute to the implementation of the substantive norms, as it regulates a procedure (a process, an order) for the implementation of rights and the implementation of duties established by substantive norms. There are also processual norms that have a completely "autonomous" meaning id est they are not directly related to the needs of the implementation of substantive norms (for example, norms that regulate processual relations in administrative proceedings) (Авер'янов, 2004).

As M. Kurylo supposes, processual norms should be understood as clearly defined rules of conduct due to the need to ensure the rights of participants in the field of a particular type of proceedings. Then he expands the scope of processual norms to the "rules of conduct for specifically authorized by the state subjects to carry out a jurisdictional activity, as well as other participants in the process (Курило, 2013).

It should be noted that the idea of the existence of substantive and processual legal norms is stable and indisputable, primarily intended to form an instrumental theoretical approach to understanding, realizing, and presenting the content of a particular legal norm.

V. Dashkovska notes that today there is no generally accepted approach to the correlation between substantive and processual law, there are many points of view on this issue. In general, summarizing their positions, it is possible to identify the following directions:

1) the whole system of law mainly consists of substantive rules. Processual norms should be recognized only those rules of conduct that have formed independent branches of law aimed at establishing a procedures for administering legal proceedings. Under this approach, processual law is represented by such branches as civil processual, commercial processual, criminal processual law and administrative processual law, which regulates the order for administrative proceedings;

2) processual norms of law are considered as rules that establish not only judicial but also an administrative procedure for resolving a legal conflict;

3) processual law is considered as a system of rules of conduct governing any law applying procedure, regardless of reasons that necessitated this legal form of activity (resolving a dispute concerning a right, establishing a legal fact, etc.);

4) processual law is considered as a system of norms establishing the order not only of law enforcement but also of any legal form of activity of state authorities and local self-government (in particular, an order of explaining current legislation by bodies of state power, an order of normative-legal acts (regulations) issuing, etc.);

5) processual law is a system of norms that establish an order for the participants' of public relations rights and duties implementation when the implementation process involves an authorized body of state power or local self-government (for example, an order for the right to a pension implementation, in which the Pension Fund of Ukraine participates), as well as when the implementation of the legal norms is conducted without the participation of any authoritative subjects (for example, 
an order for an entrepreneurial agreement concluding: the Commercial Code of Ukraine provides in what a way it is possible to suggest to conclude an agreement, in what terms an answer on the mentioned proposal may be given, as well as other procedural points);

6) processual law regulates not only the process of substantive law norms implementation but also the process of rule-making that is in a procedure that results in a certain sequence of actions is the adoption and entry into force of an act establishing the norms of law (Дашковська, 2015).

From this rather large quote, we can see that when writing theoretical scientific papers on the processual component of law, very often, there is the use of the concepts: "substantive and processual norms", "substantive and processual law", "juridical process", "administrative process", etc., as well-known, without the explanation of their content in a particular situation.

Theorist of law D. Bocharov believes that the division of law into substantive and processual is conditional, and most importantly it has a relative character (Бочаров, 2006). V. Balandin and A. Pavlushina noted: "In different dimensions, the same norm can be both substantive and processual $<\ldots>$ In our opinion, the authors summarize, it should finally be recognized that it is obviously impossible to mechanically differentiate norms of law into substantive and processual and permanently establish their belonging to a certain group" (Баландин, Павлушина, 2001).

It is worth mentioning here P. Rabinovich's no less valid statement that processuality is such a regulatory function of legal norms, which they acquire only in relation to other ("substantive") norms when interacting with them. "Substentialism" and "processualtity" of legal norms are conditional terms that mark certain functional properties of norms, due to their role in legal regulation (Рабинович, 1975).

D. Bocharov also notes that it would seem that the lack of a clear boundary separating substantive-legal and processual-legal procedures should have been an additional argument in favor of a broad understanding of the meaning of "a processual form", but processualists chose a simpler way to consider processual only that one which is directly related to the court's activity or provided by criminal-processual and civil-processual codes. Naturally, with such a definition of processuality, the issue of recognizing the processual form as a general concept in the context of law enforcement was automatically removed from the "agenda" of legal science (Бочаров, 2006).

According to J. Ziekow, process refers to the totality of administrative workflows for preparing and delivering a service (Ziekow, 2021). Two principles that guided the Administrative Process: the value of government interference and the superiority of the administrative process as a decision-making concept (Pilichowski, 2021). The growing impetus towards proceduralization in an uncertain world given the weakness of legislator brings a subsequent growing role of administrative procedure, where rules, activities and solutions are to be invented (Barnes, 2016). 
Also in the literature, there is an identification of concepts related to "substantive and processual" and as follows, in particular in Wikipedia "Processual norms (norms of processual law)": substantive law is a set of norms of a system of law that directly regulate public relations and a set of branches of law in which the main emphasis is on establishing rights and duties of subjects.

The term "substantive law" is used in jurisprudence as a notion marking such legal norms by which the state makes its influence on public relations through direct, immediate legal regulation (Wikipedia, 2021).

We would like to summarize the content of these quotations as follows.

1. The separation of substantive and processual law is appropriate only as a "learning" approach because it concentrates on the multidimensionality of the system of law, which contains both a substantive, structural component of its elements and a processual, dynamic component, in particular, as a way of existence in law as a whole, and a separate legal norm. The approach to the separation of substantive and processual law is purely conditional, based on the idea of the complexity and diversity of law as a phenomenon of reality.

2. In fact, substantive law and processual law as phenomena of legal reality are absent.

3. On the correlation between processual and substantive law in the theory of law there are many opinions. One of them is that the division depends on the views of the researcher and his goal, this division is conditional and has its inherent instrumental value of legal phenomena cognition (Кунєв, 2013).

4. Law enforcement practice, considering processual law, is limited to understanding the legal regulation of the jurisdictional process.

But these positions, in our opinion, are not enough to solve the mentioned above problem.

The purpose of the paper is to analyze and disclose the issues of theoretical and practical plan that prevent the solution of administrative law legal applying issues, which contain or are connected with the definitions of "substantive and processual law" and "norms substantive and processual law" and the development of theoretical proposals needed to solve the problems of the practical plan.

\section{Administrative law action model legal analysis}

We would like to consider the components of the activity legal organization (Кунєв, 2014) through the prism of its components personification in the substantive and processual norms.

To form our own approach to the correlation between substantive and processual in administrative law and reproduce an effective legal model of administrative law, we use the theoretical provisions proposed by Hans Kelsen, who believed that it is possible to distinguish static and dynamic theory of law, depending on greater importance is given to norms that regulate human behavior or behavior that is regulated by these norms; depending on whether the cognition is directed to legal 
norms that are created, applied and observed through acts of human behavior, or to acts of creation, application, and observance of law provided by legal norms. The subject of a static theory of law is law as a system of valid norms, law in a state of rest; the subject of a dynamic theory of law is the process of creation and application of law, law in its movement (Kelsen, 2015).

The general rules applied by judicial and administrative bodies have a dual function: 1) the definition of these bodies and a procedure they have to follow; 2) the definition of individual norms established within the framework of judicial or administrative procedure.

These two functions correspond to two categories of legal norms, which are usually divided into norms of formal and substantive law. Formal law may be understood as general rules regulating the organization and order of judicial and administrative bodies activity that is so-called civil-processual, criminalprocessual and administrative-processual law. Substantive law is understood as general norms that determine the content of judicial and administrative acts and are designated as civil, criminal and administrative law, although the rules regulating the process in judicial and administrative bodies are no less considered as civil, criminal and administrative law (Kelsen, 2015).

It is predicted that the norms applied by these bodies are related only to civil, criminal and administrative law, although these areas cannot be applied unless formal law is applied at the same time, id est law that regulates the application of civil, criminal and administrative law, the process of judicial and administrative acts issuing. Substantive law and formal law are indissolubly connected. Only in their organic connection, they form law that regulates its creation and application. Any complete legal proposal describing this law has to contain both formal and substantive elements (Kelsen, 2015).

Based on the above theoretical provisions, we think it appropriate to consider the static and dynamic model of representation of administrative law as a regulator of the environment of public administration and the administrative activity, as the activity to implement this law.

Under the approach that we regulate the administrative activity, the approach is recognized that the activity always has two components of substantive and processual, respectively, investigating administrative law and the administrative activity, we will explore groups of formal and substantive law.

Following H. Kelsen's opinion, we assume that formal law is formed by a set of both processual and substantive norms.

Formal law is a conditional set of rules aimed at implementing a certain part of the substantive norms of a general nature, which determines the standardization of a certain activity, establishing its main components that are conditions and formalities related to material objects and, accordingly, norms of substantive law.

A function of administrative law legal phenomenon description is to depict the systemic interconnection between substantive law and formal law, between 
the definition of substantive requirements and the order of their implementation in the activity.

Substantive administrative law consists of norms that describe the materialized objects, the title of which defines the basic institutions of administrative law.

Formal administrative law consists of norms that determine the process of substantive law formalization according to the procedures of administrative activity, which consist of substantive and processual norms of formal law.

The main substantive rules of formal law include public conditions and formalities, as legal means that determine the interaction of subjects in administrative activity and the delimitation of the spheres of norms effect for private and public law.

An established by legal norms limit of private and public law norms effect determines the possibilities of subjects rights and legitimate interests implementation and the necessary actions of the public administration to ensure the implementation of the tasks assigned to it (Кунєв, Дувінг, 2019).

The separation of substantive and formal law does not lead to the division of law into two parts but will help to highlight the nature of law, with all its attributes. The definition of an activity as an object of jurisprudence does not contradict the normative approach to legal understanding, but deepens it, making some changes to the object of "an activity norming (as a system) through regulations", allows making a more systematic approach to the study of state-legal phenomena and processes, and reaching new horizons in the legal activity organization, using forms of the activity and thinking organization (Кунєв, 2008).

The subjects of interaction, in the starting position, have different tasks and ways of activity implementation. The actions of public administration and the actions of subjects of private law become interdependent in their direct interaction. Legal regulation of the subjects' of interaction actions is difficult because the legal regulation of their activities separately belongs to different, diverse spheres, traditionally defined with the help of zones of legal regulation methods prevailing that are imperative or dispositive ones.

In accordance with S. Alekseev, fundamentals that express two main models of legal regulation, two types of legal material construction are dispositive and binding ones.

Formal criteria between the borders of these two legal spheres are sometimes very shaky, mobile, erased by real life, legislation and legal practice, and are portrayed by analytical jurisprudence quite reasonable and convincingly "power-subordination" and "subordination" for public law; "legal equality" and "coordination" for private law.

Public law is, in general, a different juridical world, a different "legal galaxy", and in the world-creating meaning is a sphere no less important than law itself. In essence, it is a continuation of the relevant social phenomenon that is a state, public authority with all its positive and negative potentials, which are expressed in the benefits of law, although another "quality" that is the public one. These positive qualities as a result of the democratization of society are implemented in the principles 
of subordination of the rule of the law, legal procedures for its implementation, and, more broadly, in the principles of separation of powers, republican form of governing, and, finally, in the state ensuring of human rights (Алексеев, 1999).

Public-administrative activity (Кунєв, Дувінг, 2019) is an activity, the main purpose of which is to delimit the zones of private and public law subjects' functioning or to protect the private activity from abuse from the side of public administration.

The most relevant for administrative law is the division into substantive and formal law, found by administrative law scientists teaching the administrative process and administrative-processual law. This approach does not have a significant content load, as in fact the legal regulation of activity is considered, which contains both substantive and processual norms, the division into which is also conditional. The main thing is to clarify the question (according to H. Kelsen), what we regulate and how we regulate the implementation of norms in the activity.

\section{The system of norms for the formation of the main public-administrative activity}

The subject of administrative law requires modeling and legal regulation of administrative activity according to the scheme of legal certainty by the norms of substantive and formal law; in particular, the main public-administrative activity is formed by a system of norms:

a) substantive norms that determine the general principles of public administration;

b) substantive and processual norms of formal law, which determine the general standard of subjects interaction;

c) substantive and processual norms of formal law, which determine the regulations of a particular body of public administration activity.

It is advisable to analyze the implementation of the approach for each subject of administrative law, but the approach will be general and universal for all subjects, taking into account certain minor features of the types of the administrative activity, in the first turn, the public-administrative one.

Taking into account that to implement the protective function of administrative law, we plan in public-administrative activity, the following elements may be determined (to acquire a legal form) with the help of law.

The following elements are defined by substantive norms:

- a purpose, tasks, functions, and principles of administrative activity;

- rights and legal status of subjects;

- a structure of interconnections in the system of public administration activity;

- the means by which there is a direct impact on the material of administrative activity;

- a product of administrative activity. 
The following elements are defined by formal norms:

a) conditions and public formalities;

b) subjects' actions of information transformation;

c) ways (a technology) of information transformation.

Law can simultaneously regulate a material, a method, a means, a norm, a technology, a product of the activity, and these combinations in cooperation of various acts of activity, where law is the element, will form the types of activity within the sphere of administrative law action (Кунєв, 2013).

Unified approaches to the legal regulation of administrative activity lead to the formation of a single standard for it in administrative procedure, as a standard for all administrative activities, including judicial.

The importance of administrative procedure as a standard for public-administrative activity performs a double task, which is not only the existence of a comprehensive system of principles from constitutional to the principles of public-administrative and judicial activity in the form of substantive law norms but also the implementation of these substantive norms in the activity by the formal law norms tools.

As R. Siuciński understands an administrative procedure as a key factor in the development of control over administrative power (Siuciński, 2020). Administrative procedure is an important phenomenon of administrative law (Potěšil et al., 2021). The necessity of administrative procedure and its advantages are widely acknowledged (Pünder, 2013).

According to J. Ponce, the three fundamental questions are:

- What purpose do administrative procedures serve? That is, why do must public authorities follow an administrative procedure when making a public decision?

- Is it a good or bad idea to regulate administrative procedure? If good, how best to regulate it?

- Who should regulate administrative procedures? (Ponce, 2005).

Anyways, as P. Kovač stated, legally regulated relations are a tool and a guarantee of a systemic model of good public governance. Its effectiveness must be understood as the right ratio between the common principles and necessary rules in administrative relations and the debureaucratization of other burdens on the parties (Kovač, 2020).

\section{Conclusions}

The function of describing the legal phenomenon of administrative law is to depict the systemic interconnection between substantive and formal law, between the definition of substantive requirements and the order of their implementation in the activity.

Formal law is a conditional set of norms aimed at the implementation of a certain part of the substantive norms of a general nature, which determines the standardization of a certain activity.

Substantive administrative law consists of norms that describe the materialized objects, the title of which defines the basic institutions of administrative law. Formal 
administrative law consists of norms that determine the process of formalization of substantive law according to the procedures of administrative activity, which consist of substantive and processual norms of formal law.

The main substantive norms of formal law include public conditions and formalities, as legal means that determine the interaction of subjects in administrative activity and the delimitation of the spheres of private and public law norms action.

Recently, the world practice is most exposed to the view of administrative procedure as the main legal way of public-administrative activity and public formalities organization, as the main legal means to ensure the necessary qualities of administrative activity and administrative legislation.

General approaches to the bodies of public power activity, public administrations' activity directions should be implemented within the basic procedures of the administrative activity general regulation according to the administrative procedure standards. At the same time, the standards of the administrative procedure should cover any public administration's body activity in spite of its competence sphere.

\section{Bibliography:}

1. Авер'янов В. Адміністративне право України. Академічний курс : підручник : у 2 т. Київ : Юридична думка, 2004. Т. 1 : Загальна частина. 584 с.

2. Алексеев С. Право: азбука-теория - философия (опыт комплексного исследования). Москва : Статут, 1999. 712 с.

3. Бочаров Д. Правозастосовча діяльність: поняття, функції та форми : проблемні лекції. Дніпропетровськ : АМСУ, 2006. 73 с.

4. Дашковська Т. Норми матеріального та процесуального права: до питання співвідношення. Актуальні проблеми держави і права : збірник наукових праць. Одеса : Юридична література, 2015. Вип. 75. С. 90-96.

5. Кельзен Г. Чистое учение о праве / пер. с нем. М. Антонова и С. Лёзова. 2-е изд. Санкт-Петербург : Издательский дом «Алеф-Пресс», 2015. 542 с.

6. Кунєв Ю. Адміністративний процес: проблеми визначення сутності та змісту. Публічне право. 2013. № 2. С. 51-56.

7. Кунєв Ю. Об'єкт правознавства: системодіяльнісний підхід. Право Украӥни. 2008. № 2. C. 32-35.

8. Кунєв Ю. Правова організація діяльності митної служби України: теоретичні та методологічні основи : дис. ... докт. юрид. наук : 12.00 .07 ; Харківський національний університет внутрішніх справ. Ірпінь, 2014. 400 с.

9. Кунєв Ю., Дувінг В. Публічно-адміністративна діяльність - об’єкт адміністративно-правової науки. Правова позичія. 2019. № 4(25). С. 43-50.

10. Курило М. Щодо уніфікації підстав порушень норм процесуального права. Право $i$ суспільство. 2013. № 6. С. 99-102.

11. Матеріальне право. Вікіnедія. URL: https://uk.wikipedia.org/wiki/Матеріальне_право.

12. Принципы юридического процесса / В. Баландин, А. Павлушина ; под общ. ред. В. Ведяхина. Тольятти : Издательство ВУиТ, 2001. 150 с.

13. Рабинович П. Упрочение законности - закономерность социализма: вопросы теории и методологии исследования. Львов, 1975. 260 с.

14. Barnes J. Towards a third generation of administrative procedures. First draft - 2016 Conference on Comparative Administrative Law, April 29-30, 2016. P. 1-27. 
URL: https://law.yale.edu/sites/default/files/area/conference/compadmin/compadmin16_barnes_ towards.pdf.

15. Implementation of laws on general administrative procedure in the Western Balkans / ed. by E. Pilichowski. SIGMA Papers. 2021. № 62. 92 p. URL: https://www.oecd-ilibrary.org/ docserver/ e5162057-en.pdf?expires $=1643614493 \& \mathrm{id}=\mathrm{id} \&$ accname $=$ guest\&checksum $=4 \mathrm{DD} 33$ 41E7B7D02ABC03E664BF01001B5.

16. Kovač P. Debureaucratization Limits in Administrative Procedures Codification: Lessons from Slovenia. Administrative Sciences. 2020. Vol. 11. Issue 1. URL: https:// www.mdpi.com/2076-3387/11/1/1/htm.

17. Ponce J. Good Administration and Administrative Procedures. Indiana Journal of Global Legal Studies. 2005. Vol. 12. Issue 2. P. 551-588. URL: https://www.repository.law.indiana.edu/ cgi/viewcontent.cgi? article $=1310 \&$ context $=$ ijgls.

18. Pünder H. German administrative procedure in a comparative perspective - Observations on the path to a transnational ius commune proceduralis in administrative law. International Journal of Constitutional Law. 2013. Vol. 11. Issue 4. P. 940-961. URL: https://jeanmonnetprogram.org/ wp-content/uploads/2014/12/Punder.pdf.

19. Simplification of Administrative Procedure on the Example of the Czech Republic, Poland, Slovakia, and Hungary (V4 Countries) / L. Potěšil, K. Rozsnyai, J. Olszanowski, M. Horvat. Administrative Sciences. 2021. Vol. 11. Issue 9. URL: https://www.mdpi.com/2076-3387/11/1/9/htm.

20. Siuciński R. Administrative procedure as a key factor in development of control over administrative power - a European perspective. Juridical Tribune. 2020. Vol. 10. Issue 3. P. 427-441.

21. Ziekow J. Administrative Procedures and Processes. Public Administration in Germany / S. Kuhlmann, I. Proeller, D. Schimanke, J. Ziekow (eds.). London : Palgrave Macmillan, 2021. P. 163-183. URL: https://link.springer.com/content/pdf/10.1007\%2F9783-030-53697-8_11.pdf.

\section{References:}

1. Averianov, V. (2004). Administratyvne pravo Ukrainy. Akademichnyi kurs: pidruchnyk [Administrative law of Ukraine. Academic course: textbook], in 2 vols., vol. 1: Zahalna chastyna [The general part]. Kyiv : Yurydychna dumka [in Ukrainian].

2. Alekseev, S. (1999). Pravo: azbuka - teoriya - filosofiya (opyt kompleksnogo issledovaniya) [Law: ABC - theory - philosophy (experience of complex research)]. Moscow: Statut [in Russian].

3. Bocharov, D. (2006). Pravozastosovcha diialnist: poniattia, funktsii ta formy: problemni lektsii [Law enforcement activity: concepts, functions and forms: problem lectures]. Dnipropetrovsk : AMSU [in Ukrainian].

4. Dashkovska, T. (2015). Normy materialnoho ta protsesualnoho prava: do pytannia spivvidnoshennia [Norms of substantive and procedural law: the question of correlation]. Aktualni problemy derzhavy i prava: zbirnyk naukovykh prats. Odesa : Yurydychna literatura, issue 75, pp. 90-96 [in Ukrainian].

5. Kelsen, H. (2015). Chistoe uchenie o prave [Pure Theory of Law], transl. from German M. Antonov, S. Lezov. $2^{\text {nd }}$ ed. Saint Petersburg : Izdatel'skiy dom "Alef-Press" [in Russian].

6. Kuniev, Yu. (2013). Administratyvnyi protses: problemy vyznachennia sutnosti ta zmistu [Administrative process: problems of determining the essence and content]. Publichne pravo, no. 2, pp. 51-56 [in Ukrainian].

7. Kuniev, Yu. (2008). Obiekt pravoznavstva: systemodiialnisnyi pidkhid [Object of jurisprudence: system-activity approach]. Pravo Ukrainy, no. 2, pp. 32-35 [in Ukrainian]. 
8. Kuniev, Yu. (2014). Pravova orhanizatsiia diialnosti mytnoi sluzhby Ukrainy: teoretychni ta metodolohichni osnovy [Legal organization of the customs service of Ukraine: theoretical and methodological foundations]. Doctor's thesis. Irpin [in Ukrainian].

9. Kuniev, Yu., Duvinh, V. (2019). Publichno-administratyvna diialnist - obiekt administratyvno-pravovoi nauky [Public-administrative activity is an object of administrativelegal science]. Pravova pozytsiia, no. 4(25), pp. 43-50 [in Ukrainian].

10. Kurylo, M. (2013). Shchodo unifikatsii pidstav porushen norm protsesualnoho prava [Regarding the unification of the grounds for violations of procedural law]. Pravo $i$ suspilstvo, no. 6, pp. 99-102 [in Ukrainian].

11. Wikipedia (2021). Materialne pravo [Substantive law]. URL: https://uk.wikipedia.org/ wiki/Матеріальне_право [in Ukrainian].

12. Balandin, V., Pavlushina, A. (2001). Printsipy yuridicheskogo protsessa [Principles of the legal process]. Tolyatti: Izdatel'stvo VUiT [in Russian].

13. Rabinovich, P. (1975). Uprochenie zakonnosti - zakonomernost' sotsializma: voprosy teorii i metodologii issledovaniya [Consolidation of the rule of law is the regularity of socialism: questions of theory and methodology of research]. Lviv [in Russian].

14. Barnes, J. (2016). Towards a third generation of administrative procedures. First draft 2016 Conference on Comparative Administrative Law (April 29-30, 2016), pp. 1-27. URL: https:// law.yale.edu/sites/default/files/area/conference/compadmin/compadmin16_barnes_towards.pdf [in English].

15. Pilichowski, E. (ed.) (2021). Implementation of laws on general administrative procedure in the Western Balkans. SIGMA Papers, no. 62. URL: https://www.oecd-ilibrary.org/docserver/ e5162057-en.pdf?expires $=1643614493 \& i d=i d \&$ accname $=$ guest\&checksum=4DD3341E7B7D0 2ABC03E664BF01001B5 [in English].

16. Kovač, P. (2020). Debureaucratization Limits in Administrative Procedures Codification: Lessons from Slovenia. Administrative Sciences, vol. 11, issue 1. URL: https://www.mdpi.com/ 2076-3387/11/1/1/htm [in English].

17. Ponce, J. (2005). Good Administration and Administrative Procedures. Indiana Journal of Global Legal Studies, vol. 12, issue 2, pp. 551-588. URL: https://www.repository.law.indiana.edu/ cgi/viewcontent.cgi? article $=1310 \&$ context=ijgls [in English].

18. Pünder, H. (2013). German administrative procedure in a comparative perspective - Observations on the path to a transnational ius commune proceduralis in administrative law. International Journal of Constitutional Law, vol. 11, issue 4, pp. 940-961. URL: https://jeanmonnetprogram.org/wp-content/uploads/2014/12/Punder.pdf [in English].

19. Potěšil, L., Rozsnyai, K., Olszanowski, J., Horvat, M. (2021). Simplification of Administrative Procedure on the Example of the Czech Republic, Poland, Slovakia, and Hungary (V4 Countries). Administrative Sciences, vol. 11, issue 9. URL: https://www.mdpi.com/ 2076-3387/11/1/9/htm [in English].

20. Siuciński, R. (2020). Administrative procedure as a key factor in development of control over administrative power - a European perspective. Juridical Tribune, vol. 10, issue 3, pp. 427-441 [in English].

21. Ziekow, J. (2021). Administrative Procedures and Processes. Public Administration in Germany / S. Kuhlmann, I. Proeller, D. Schimanke, J. Ziekow (eds.). London : Palgrave Macmillan, pp. 163-183. URL: https://ink.springer.com/content/pdf/10.1007 \%2F978-3-030-53697-8_11.pdf [in English]. 


\title{
АДМІНІСТРАТИВНЕ ПРАВО: МАТЕРІАЛЬНІ, ПРОЦЕСУАЛЬНІ ТА ФОРМАЛЬНІ СКЛАДНИКИ
}

\author{
Юрій Кунєв, \\ професор кафедри конституційного і адміністративного права \\ юридичного факультету \\ Національного авіаційного університету, \\ доктор юридичних наук, професор \\ orcid.org/0000-0002-5952-2052 \\ kunev@ukr.net \\ Оксана Миронець, \\ доцент кафедри конституційного і адміністративного права \\ юридичного факультету \\ Національного авіаційного університету, \\ кандидат юридичних наук, докторант \\ orcid.org/0000-0002-5035-2384 \\ o.m.myronets@ukr.net
}

\begin{abstract}
Мета статті полягає в аналізі та розкритті питань теоретичного і практичного плану, що перешкоджають розв'язанню проблем правозастосування норм адміністративного права, які містять або пов'язані з дефінічіями «матеріальне і процесуальне право» та «норми матеріального і процесуального права», а також у розробленні теоретичних пропозицій, щзо необхідні для розв'язання проблем практичного плану. Методи дослідження. У роботі використані комплексний підхід до створення теоретичної картини об'єкта та застосування методологічної схеми «подвійного знання» про об'єкт як такий і про знання, щуо його описують $і$ зображують; метод порівняльно-правового й доктринального пізнання адміністративного законодавства; метод узагальнення та моделювання нових теоретичних знань адміністративного права. Результати. Визначено проблеми подальшого розвитку теорї та практики адміністративного права, запропоновано теоретичний підхід для їх розв'язання. Встановлено, щзо предмет адміністративного права потребує моделювання та правового регулювання адміністративної діяльності за схемою правової визначеності нормами матеріального й формального права. Матеріальне адміністративне право складається з норм, що описують матеріальні об'єкти, назва яких визначає основні інститути адміністративного права. Формальне адміністративне право складається з норм, що визначають процес формалізачії матеріального права за проиедурами адміністративноїдіяльності, які складаютьсязматеріальних іпрочесуальних норм формального права. До основних матеріальних норм формального права віднесено публічні умови й формальності як правові засоби, щзо визначають взаємодію суб'єктів в адміністративній діяльності та розмежування сфер дії норм приватного і публічного права. Висновки. Аргументовано, щзо практична реалізація підходів на основі теоретичного положення поділу на матеріальне й формальне адміністративне право означає формування адміністративної процедури як єдиного стандарту для всієї адміністративної діяльності, зокрема й судової.
\end{abstract}

Ключові слова: адміністративне право, матеріальне право, формальне право, адміністративна діяльність, публічно-адміністративна діяльність, публічні формальності, матеріальні норми, процесуальні норми. 